\title{
TEACHING THROUGH DISCOURSE
}

CKertaeva Z., ORCID: 0000-0003-0594-1996 Alisher Navoi Tashkent State University of Uzbek Language and Literature, Tashkent, Uzbekistan, zaurekertaeva@gmail.com

\section{ОБУЧЕНИЕ ЧЕРЕЗ ДИСКУРС}

(CКертаева 3. С., ORCID: 0000-0003-0594-1996 Ташкентский государственный университет узбекского языка и литературы им. А. Навои, г. Ташкент, Узбекистан, zaurekertaeva@gmail.com

Abstract. The article discusses the role of discourse in foreign language teaching by studying previous investigations in the field of discourse analysis and communicative approach-based language teaching. Moreover, it presents an analysis of some authentic examples of target language use to prove the role of discourse to prevent possible miscommunication.

Аннотация. В статье рассматривается роль дискурса в обучении иностранному языку путем изучения предыдущих исследований в области дискурс-анализа и преподавания языка на основе коммуникативного подхода. Кроме того, он представляет анализ некоторых достоверных примеров использования целевого языка, чтобы доказать роль дискурса для предотвращения возможного недопонимания.

Keywords: discourse, discourse analysis, communicative approach, communicative competence, linguistic competence, sociolinguistic competence, discourse competence, strategic competence.

Ключевые слова: дискурс, дискурс-анализ, коммуникативный подход, коммуникативная компетентность, лингвистическая компетентность, социолингвистическая компетентность, дискурсивная компетентность, стратегическая компетентность.

\section{Introduction}

Since Communicative Approach has been introduced in language learning and teaching, it has become a need for language teachers to be able to integrate other disciplines rather than approaching the language separately. Discourse analysis, one of those areas, has a number of definitions from a variety of perspectives. Before we go down to discuss approaches to the definition of discourse analysis, the word "discourse" needs defining. According to Celce-Murcia \&Olshtain (2000), defining a discourse should not be limited with formal and functional approaches [1]. They claim defining discourse as a unit of more than one sentence (formal approach) is not optimal because discourse can be as short as "Stop!" "No smoking!"; or considering discourse as a unit of language in use is too general. Having been introduced by Z.Harris first, discourse analysis developed as a result of investigations made in the fields of linguistics, psychology, anthropology and sociology [2]. Celce_Murcia\&Olshtain (2000) define this discipline in comparison with text linguistics saying that text linguistics deals with written texts from different genres and fields, while discourse analysis covers more cognitive and social perspectives on language use and communicative exchanges [1]. 
Abovementioned disciplines along with discourse analysis share common interests in how real people use real language or language in action which is immediate interest of language teachers, particularly, about how to make teaching materials, purpose or activity authentic, in the end helping learners to become more proficient in the target language. McCarthy claims that although language experienced teachers may feel what material authentic or natural is; or when it is beneficial to use artificial language, detailed insight into how texts are structured beyond sentence level; how talk follows regular patterns in a wide range of situations; and how discourse norms differ from culture to culture should be offered [2]. These all prove the role of discourse and discourse analysis in language teaching and learning.

Many researchers have suggested different types of discourse analysis - spoken vs written discourse, genre analysis, conversation analysis, cohesion analysis and critical analysis. With regard to Celce-Murcia\&Olshtain, there are no clear boundaries between spoken and written discourse. In other words, some speech can be prepared in advance in written way, while spontaneous speech can be recorded and analysed closely [1]. Similarly, spontaneous speech can be recorded and transcribed to enable close analysis. Another unclearness can be about that some written discourse is informal and speechlike (personal letters and email), while other written is carefully planned, in formal style, undergoing multiple revision (doctoral dissertations or legal documents).

\section{Main Body}

Although there are many types of discourse (critical discourse, genre analysis, conversation analysis, cohesion analysis, rhetorical structure theory), pedagogical discourse analysis has a special role in language teaching like identifying problems and designing activities to help learners overcome the problems. These problems can be related to miscommunication between native and non-native speakers of the language [1].

Reasons for communication breakdowns may vary - grammar, pronunciation, lexical or pragmatic inaccuracies. It is pedagogical discourse analysis which finds out the reason of miscommunication and help language teachers to bring it to the classroom as an example and practice the ways of avoiding such problems.

Celce-Murcia\&Olshtain consider that three main developments in language studies have given a rise to discourse based approaches to language teaching. They are 1) linguistic theories that include discourse analysis with grammar, lexicon and phonology; 2) work in communicative approaches in language teaching; and 3) theoretical models of communicative competence [1].

Discourse based approach to language teaching is a result of opposition of a number of scholars to sentence - level paradigm and context-free model of Chomsky. In other words, both Hymes, who introduced the term of communicative competence, and functional linguist Halliday argue that language includes not only innate mechanisms for language acquisition, but also discourse and use; grammar, lexicon, phonology as integral constituents. The specific feature of this approach lies in analyzing coherent fragments of authentic language rather than artificially constructed sentences, which are typical to Chomskyan school.

Other methodologists such as van Ek and Wilkins (1976) suggested language instruction should not be limited with only grammar but notions like time, space and quantity; and social functions like request, apology and complaints should also be taken into consideration [3].

Based on Hymes ' notion of communicative competence, developed four major components of communicative competence in second language learning; 1) linguistic competence (ability to produce and interpret meaningful utterances and bear conventional meaning); 2) sociolinguistic competence (awareness of ways where language forms are chosen considering setting, relationship of communication partners, and communicative intentions); 3) discourse competence (ability to select related strategies to construct and interpret texts, combining sociocultural knowledge and top- 
down communicative intent); 4) strategic competence (ability to find out solutions to communication problems, particularly, by rephrasing, asking for clarification or eliciting) [3].

\section{Discourse- based grammar and vocabulary}

Discourse based grammar highlights the role of cohesion (usually provided with use of articles, various types of pronouns, conjunctions and others) and coherence (when the independent sentences are linked to make one unique meaningful piece of speech e.g paragraph) in construction of grammatically correct sentences. Having learnt from illustration of Celce-Mercia\&Olshtain (2000), the author provides some examples for referential ties, substitute expressions, ellipsis and logical connectors [1].

\begin{tabular}{|c|c|c|}
\hline Cohesive devices & Examples & Analysis \\
\hline Referential Ties & $\begin{array}{l}\text { In our home, we keep an old telephone. It } \\
\text { was brought by my late father. As he used } \\
\text { to work as a school director, he probably } \\
\text { needed the telephone to be reachable to his } \\
\text { seniors. }\end{array}$ & $\begin{array}{l}\text { The pronoun it refers to telephone, } \\
\text { pronoun he to father, definite article the } \\
\text { shows the item is already familiar to the } \\
\text { reader or listener. }\end{array}$ \\
\hline $\begin{array}{l}\text { Substitute } \\
\text { Expressions }\end{array}$ & $\begin{array}{l}\text { a) I will take the red dress, not the black } \\
\text { one. } \\
\text { b) My students are always lying to me. I } \\
\text { cannot understand why they are doing so. }\end{array}$ & $\begin{array}{l}\text { One is nominal substitute for dress and } \\
\text { doing is verb phrase substitute for always } \\
\text { lying }\end{array}$ \\
\hline Ellipsis & $\begin{array}{l}\text { - Who is absent today? } \\
\text { Shahlo } \\
\text { - What would you like to drink? } \\
\quad \text { Coffee, please }\end{array}$ & $\begin{array}{l}\text { Ellipsis is in the predicate (is absent) } \\
\text { Ellipsis is in the subject and verb (I } \\
\text { would like to) }\end{array}$ \\
\hline Logical connectors & $\begin{array}{l}\text { Despite the heavy rain, we decided to have } \\
\text { some walk. }\end{array}$ & $\begin{array}{l}\text { The connector defines the relationship of } \\
\text { two clauses (contrast relationship) }\end{array}$ \\
\hline
\end{tabular}

In discourse-based vocabulary, we can investigate the role of use of synonyms, antonyms, exact and partial repetitions, part -whole relationships, words in the same semantic class, class genus word [5].

\begin{tabular}{|c|c|c|}
\hline Lexical categories & Example & Analysis \\
\hline Synonyms & $\begin{array}{l}\text { She is overconcerned about her problems. She is } \\
\text { thinking of getting a loan from the bank to help } \\
\text { her out of financial predicament. }\end{array}$ & $\begin{array}{l}\text { Problem and predicament are } \\
\text { synonyms creating a lexical tie. }\end{array}$ \\
\hline Antonyms & $\begin{array}{l}\text { Don't you think Michael is stupid } \\
\text { Yeah, he is not that intelligent. }\end{array}$ & $\begin{array}{l}\text { Stupid and intelligent creating a } \\
\text { lexical tie }\end{array}$ \\
\hline $\begin{array}{l}\text { Exact or partial } \\
\text { lexical repetitions }\end{array}$ & $\begin{array}{l}\text { When we compare the complexity of different } \\
\text { languages, there is no clear criterium to measure } \\
\text { how complex one language is than the other one. }\end{array}$ & $\begin{array}{l}\text { Noun and adjective words of one } \\
\text { root help the tie discourse } \\
\text { lexically }\end{array}$ \\
\hline $\begin{array}{l}\text { Part or whole } \\
\text { relationships }\end{array}$ & $\begin{array}{l}\text { That is a professionally designed lesson plan, I } \\
\text { especially liked the variety of interaction modes }\end{array}$ & $\begin{array}{l}\text { The fact that interaction modes } \\
\text { are prototypical part of lesson } \\
\text { planning creates lexical cohesion }\end{array}$ \\
\hline $\begin{array}{l}\text { Words in the same } \\
\text { semantic class }\end{array}$ & $\begin{array}{l}\text { You can get there in many ways. If you would } \\
\text { like to enjoy long journey and scenery of desert, } \\
\text { go by train or bus. If you are short of time, it is } \\
\text { better to go by plane. }\end{array}$ & $\begin{array}{l}\text { Train, bus and plane belong into } \\
\text { the same semantic class. }\end{array}$ \\
\hline $\begin{array}{l}\text { Class/genus word } \\
\text { member }\end{array}$ & $\begin{array}{l}\text { Thousands of people are suffering from } \\
\text { coronavirus. The disease first has been recorded } \\
\text { in China, now reaching other neighbouring } \\
\text { countries. }\end{array}$ & $\begin{array}{l}\text { The relationship between } \\
\text { coronavirus and disease creates } \\
\text { lexical cohesion }\end{array}$ \\
\hline
\end{tabular}

Discourse-based listening and reading 
When we listen, we use not only aural recognition (stress, pause and intonation), but also lexico - grammatical signals (discourse markers and word order). In reading, teachers help learners to become efficient and independent readers by doing classroom intensive reading in chunks, teaching how to use context to decode the meaning of unknown words by controlled dictionary use and helping them summarise the text first by chunks, then as a whole [1,4]. In general, a good interpretation is achievable when writer's intention and readers expectations meet.

\section{Discourse based writing and speaking}

Spoken miscommunication can happen because of a number of reasons:

a) inaccuracy or inappropriateness in language;

b) not sharing the same culture, background information, and expectations;

c) first language interference. In order to avoid those problems, a teacher is suggested to firstly bring authentic activities to the classroom like role playing using different speech acts (requesting, complaining or ordering), oral presentations, debates and others.

Secondly, teachers should guide the learners to use communication strategies with linguistic and socio-cultural knowledge [5].

When one piece of writing is created, the author needs to consider readers ' background knowledge and expectations. In other words, the notion of absent reader (who does not share physical and temporal context with the writer) should not be disregarded. Learners' written discourse can be improved by helping them compose and teaching them to use feedback to edit, correct and improve the work.

\section{Conclusion}

In conclusion, in contemporary world, as we apply communicative approach in foreign language teaching, discourse and language teaching are interrelated. EFL teachers should not forget that a language cannot be taught alone, it should always integrate authentic communicative intentions, materials and activities. To accomplish these objectives, teachers are suggested to implement discourse - based teaching for all language subskills (pronunciation, grammar and vocabulary) and skills (listening, reading, writing and speaking). When applying this approach, different components of communicative competence (linguistic, sociolinguistic, discourse and strategic); and careful selection and design of activities should be regarded.

\section{References}

1. Milne G. V. An Overview of Discourse Analysis and Its Usefulness in TESOL. 2000.

2. Goodwin J. et al. Teaching English as Second or Foreign Language // Teaching Pronunciation. 2001. Vol. 3.

3. Jalolov J.J., Mahkamova G.T., Ashurov S.S. English Teaching Methodology. Fan va texnologiya nashriyoti. Tashkent. 2015.

4. McCarthy M., Matthiessen C., Slade D. 4 Discourse Analysis //An Introduction to Applied Linguistics. Routledge, 2013. P. 63-79.

5. Halliday M. A. K., Hasan R. Cohesion in english. Routledge, 2014.

\section{References}

1. Milne, G. V. (2000). An Overview of Discourse Analysis and Its Usefulness in TESOL.

2. Goodwin, J., Celce-Murcia, M., Brinton, D. M., \& Snow, M. A. (2001). Teaching English as Second or Foreign Language. Teaching Pronunciation, 3.

3. Jalolov, J. J., Mahkamova, G. T., \& Ashurov, S. S. (2015) English Teaching Methodology. Fan va texnologiya nashriyoti. Tashkent 
4. McCarthy, M., Matthiessen, C., \& Slade, D. (2013). 4 Discourse Analysis. In An Introduction to Applied Linguistics (pp. 63-79). Routledge.

5. Halliday, M. A. K., \& Hasan, R. (2014). Cohesion in english. Routledge.

Работа поступила

в редакцию 09.02.2020 г.
Принята к публикациии 15.02.2020 2.

Ссылка для циитирования:

Kertaeva Z. Teaching Through Discourse // Бюллетень науки и практики. 2020. Т. 6. №3. C. 416-420. https://doi.org/10.33619/2414-2948/52/49

Cite as (APA):

Kertaeva, Z. (2020). Teaching Through Discourse. Bulletin of Science and Practice, 6(3), 416-420. https://doi.org/10.33619/2414-2948/52/49 